\title{
APPLICATION OF A MATHEMATICAL MODEL FOR THE MINIMIZATION OF COSTS IN A MICRO-COMPANY OF THE GRAPHIC SECTOR
}

Paulo Cesar Chagas Rodrigues Instituto Federal de Educação, Ciência e Tecnologia de São Paulo, Brazil E-mail: paulo.rodrigues@ifsp.edu.br

Fernando Augusto Silva Marins Universidade Estadual Paulista, Campus Guaratinguetá, Brazil E-mail: fmarins@feg.unesp.br

Fernando Bernardi de Souza Universidade Estadual Paulista, Campus Bauru, Brazil E-mail: fbernardi@feb.unesp.br

Submission: 08/04/2015 Accept: 01/05/2015

\section{ABSTRACT}

Supply chain management, postponement and demand management are one of the operations of strategic importance for the economic success of organizations, in times of economic crisis or not. The objective of this article is to analyze the influence that a mathematical model focused on the management of raw material stocks in a microenterprise with seasonal demand. The research method adopted was of an applied nature, with a quantitative approach and with an exploratory and descriptive objective. The technical procedures adopted were the bibliographical survey, documentary analysis and mathematical modeling. The development of mathematical models for solving inventory management problems may allow managers to observe deviations in trading methods, as well as to support rapid decisions for possible unforeseen market or economic variability.

Keyword: Postponement; Supply Chain Management; Demand Management; Inventory Management; Mathematical Modeling 
DOI: 10.14807/ijmp.v8i5.617

\section{INTRODUCTION}

Since ECO92, organizations have begun to worry about the conscious consumption of raw materials and production processes, aiming to reduce waste and costs that can be minimized.

And mathematical modeling meets the managers' longings, as it can help in making decisions about how much, how, where and when to buy, so that less waste is consumed.

How to reduce cost of production without affecting the quality and availability of the product in the market? From the strategy of postponing inventories. This strategy combined with management can allow a reduction in the cost of the product, because this is talking about reducing the risk of loss of the finished product, because it has a high value added, increased flexibility in adapting the needs of the market.

The research method adopted was of an applied nature, with a quantitative approach and with an exploratory and descriptive objective. The technical procedures adopted were the bibliographical survey, documentary analysis and mathematical modeling.

The purpose of this article is to analyze the influence that a mathematical model focused on the management of raw materials inventories in a company with make-to-stock production system and with seasonal demand.

\section{THEORETICAL REFERENCE}

According to Edalatkhah (2006), in the new economy, supply chains are needed to serve varied markets around the world, set custom product deliveries, change planning, never together with speed and accuracy considered possible before. Managers need to work with multiple partners to monitor the activities that are being run together in order to solve problems and delays that may occur.

According to The Global Supply Chain Forum, supply chain management consists of integrating key processes from consumers to the producer of raw materials. GCS involves several areas, such as forecasting demand, purchasing, production, distribution, inventory and transportation, interacting in strategic, tactical and operational perspectives (MCADAM and MCCORMACK, 2001). 
According to Tan (2002), GCS involves the integration of business processes through the supply chain, encompassing the coordination of activities and processes not only within an isolated organization, but among all those that make up the supply chain.

For Rodrigues and Oliveira (2009), demand management is a practice that allows managing and coordinating the supply chain in the opposite direction, that is, from the consumer to the supplier, in which consumers initiate actions for the supply of products making the Productive system.

Darú and Lacerda (2005) and Perazza and Rodrigues (2010) describe that manufacturing for stock is a common practice, whenever the demand can be predicted, being able to take advantage of off-season moments to be produced, using resources better and loading them more Balanced. But, this policy has some disadvantages, which would be the high cost of storage and the difficulty of predicting what will be sold.

According to Van Hoek and Dierdonck (2000), Verol (2006) and Zang and Tan (2010), the concept of postponement is that the risk and costs of uncertainty lie in the differentiation (of form, place or time) of products that occurs during (a) product design: the specific content of the delayed (delayed) operation, (b) process: the time at which the activities are carried out, the activities of manufacturing, storage and delivery, based on the characteristics of the product / process in the supply chain: Are delayed in the process, and (c) place: the location where the postponement takes place.

$\mathrm{Ng}$ and Chung (2008) comment that the strategic placement of the point of decoupling of the supply chain, the strategy of postponement can be used. The goal of postponement is to increase the efficiency of the supply chain by moving product differentiation (at the point of dissociation) closer to the end user. Because risk and uncertainty are the costs linked to the differentiation of goods and the differentiation could occur in the product itself and / or the geographic dispersion of inventories.

Form postponement consists of manufacturing a base or standard product in sufficient quantities to achieve economies of scale, while finishing features such as color, packaging, etc. Are postponed until consumer applications are received and are classified into four levels: labeling or labeling, packaging, assembly and 
DOI: 10.14807/ijmp.v8i5.617

manufacturing (FERREIRA; BATALHA, 2007).

Mendes et al. (2008) based on Zinn (1990) describe and classify in 4 the existing subdivisions in the postponement of form that they describe a brief definition.

a) Postponement of labeling: Products are stored without any sort of classification. The labels and labels will be affixed when an order is made, and the customer specifies the mark that will identify the final product;

b) Manufacturing postponement: The last manufacturing steps are only completed after confirmation of the customer's order. Semi-finished products or even in the form of inputs are stocked so that the differentiation of the merchandise takes place at a time or place closer to the demand;

c) Product postponement: Products can be designed following a logic of modules, or even standardized components to facilitate further differentiation; And

d) Process postponement: Production and distribution can be designed in a way that allows the differentiation of the product downstream and upstream of the supply chain.

Yang, Burns and Backhouse (2003), Engelseth (2007) argue that place postponement involves the delay of transporting goods downstream in the chain until the orders are received, thus keeping the goods centrally and not having them in a specific place.

According to Wallin, Rungtusanatham and Rabinovich (2006), Bailey and Rabinovich (2006) and Drohomeretski, Cardoso and Costa (2008), the time delay strategy assumes that the product will be requested from the supplier only when a customer request, Which will enable the reduction of stock levels and the obsolescence of the product.

\section{MODELING}

The model can be considered causal, since it depends on present or past conditions, but also on dynamics, since the variables vary in time, in which the solution consists of the constant and temporary, deterministic regimes, when the result can be calculated exactly and Because the outputs are linearly dependent on 
DOI: 10.14807/ijmp.v8i5.617

inputs and possible disturbances.

It was chosen here, to facilitate the understanding of the modeling stage, considering only two products, being its generalization evident. We considered 12 months $(\mathrm{N})$ of production scheduling. Decision variables, Xij, refer to the quantities to be produced of products $i$ in period $j$. The unit production costs of each product, its storage costs, and the percentage annual cost of annual insurance of inventories of finished products are known.

The auxiliary variables $\mathrm{Y} 1$ to $\mathrm{Y} 7$ refer to the parameters of the raw materials used for the production of the products i. These variables will allow to measure the total quantities of raw materials to be used to produce during the 12-month period.

It should be noted that in practice, according to information from the managers of the companies studied, the variables Xij are influenced by the estimated demand according to the information of the years 2010 and 2011, in order to allow the forecast for the years 2011 and 2012 respectively.

\section{Indexes:}

$i \quad$ Is the index linked to the products, $i \in\{1,2, \ldots, n\}$;

$j \quad$ Is the index linked to the products, $j \in\{1,2, \ldots, m\}$.

\section{Parameters:}

$C_{j} \quad$ Cost $[\mathrm{R} \$]$ inventory in the period $\mathrm{j}$;

$\mathrm{Ej}_{\mathrm{j}} \quad$ Cost of purchasing the paper in period $\mathrm{j}$;

$G_{j} \quad$ Cost $[\mathrm{R} \$]$ of wire purchase in period $\mathrm{j}$;

$F_{j} \quad$ Cost $[\mathrm{R} \$]$ of ink in period $\mathrm{j}$;

$\mathrm{O}_{\mathrm{ij}} \quad$ Cost $[R \$]$ of sale loss associated with product $\mathrm{i}$ in period $\mathrm{j}$;

$h_{i j} \quad$ Cost rate [\%] of annual insurance of product $\mathrm{i}$ in period $\mathrm{j}$;

$\mathrm{CP}_{\mathrm{ij}} \quad$ Cost $[\mathrm{R} \$]$ of production of product $\mathrm{i}$ in period $\mathrm{j}$;

$D_{i j} \quad$ Demand of product i in period j;

$\mathrm{DP}_{\mathrm{j}} \quad$ Demand of the raw material paper in period $\mathrm{j}$;

$\mathrm{DA}_{\mathrm{j}} \quad$ Wire raw material demand in period $\mathrm{j}$; 
DOI: 10.14807/ijmp.v8i5.617

$\mathrm{DT}_{\mathrm{j}} \quad$ Ink raw material demand in period $\mathrm{j}$;

\section{Variables:}

$X_{i j} \quad$ Estimated quantity [unit] of product $\mathrm{i}$ in period $\mathrm{j}$;

$P_{j} \quad$ Quantity $[\mathrm{kg}]$ of paper to be purchased in period $\mathrm{j}$;

$T_{\tilde{j}} \quad$ Quantity [l] of ink to be purchased in period $\mathrm{j}$;

$A_{j} \quad$ Quantity [kg] of wire to be acquired in period j;

$\rho_{i j} \quad$ Quantity ceased to be produced from product i in period j;

$\mathrm{PA}_{j} \quad$ Level of inventory of the raw material paper in period $\mathrm{j}$;

$\mathrm{AA}_{j} \quad$ Leveling of inventory of the raw material wire in period $\mathrm{j}$;

$\mathrm{TA}_{j} \quad$ Leveling of the stock of raw ink in period $\mathrm{j}$;

$W_{i j} \quad$ Level and stock of product $\mathrm{i}$ in period $\mathrm{j}$;

The objective function (1) of the proposed model for $n$ planning periods, associated with the reduction of raw material, product in process and finished product stocks, seeks to minimize the respective costs of production and storage of raw material stocks And finished product:

The objective function (1) presents the minimization of the total cost, which is represented by $Z$.

$\operatorname{Min} Z=\sum_{i=1}^{m} \sum_{j=1}^{n}\left(C P_{i j} \cdot X_{i j}+C_{j} W_{i j}+T_{j} \cdot F_{j}+A_{j} \cdot G_{j}+P_{j} \cdot E_{j}+\rho_{i j} \cdot O_{i j}\right) \cdot h_{i j}$

The Restriction (2) leveling of paper stock in period j..

$P A_{j}=P A_{j-1}+P_{j}-D P_{j}, j=1,2, \ldots, m$

A Restriction (3) wire stock leveling in period j.

$A A_{j}=A A_{j-1}+A_{j}-D A_{j}, j=1,2, \ldots, m$

The Restriction (4) ink leveling in period j.

$T A_{j}=T A_{j-1}+T_{j}-D T_{j}, j=1,2, \ldots, m$

The Restriction (5) product leveling of product i in period $\mathrm{j}$. 
$W_{i j}=W_{i j-1}+X_{i j}-D_{i j}, i=1,2, \ldots, n, \quad j=1,2, \ldots, m$

The Restriction (6) loss of sale of product $i$ in period $j$.

$\rho_{i j}=D_{i j}-\left(X_{i j}+W_{i j-1}\right), i=1,2, \ldots, n, \quad j=1,2, \ldots, m$

The Restriction (7) presents the domain of the variables.

$P_{j} \in I^{+}, T_{j} \in I^{+}, A_{j} \in I^{+}, X_{i j} \in I^{+}, P A_{j} \in I^{+}, A A_{j} \in I^{+}, T A_{j} \in I^{+}, W_{i j} \in I^{+}$,
$i=1,2, \ldots, n, \quad j=1,2, \ldots, m$

\section{COMPANY}

The company under study employs approximately seventy professionals and has a constructed area of approximately $500 \mathrm{~m}^{2}$.

The production of the company meets part of the demand of the southwestern region of São Paulo, the focus of its production are carbon reels for POSs aimed at commercial institutions.

Currently the company has approximately five hundred direct customers, who buy their product for use in shops, bars and restaurants.

Table 1 shows the composition of the objects studied and their units of measurement. These two products served to study the behavior of the model in relation to the strategies adopted by the managers during the years of 2012 .

Data collection was done through interviews with the manager of the company and through the analysis of documents referring to the production of products 1 and 2 in the year 2012.

Table 1: Raw Materials and Company Products C

\begin{tabular}{|l|l|}
\hline \multicolumn{1}{|c|}{ Customized two-color POS coil X1 } & \multicolumn{1}{c|}{ Customized one-color POS coil X2 } \\
\hline Y1: Paper $55 \mathrm{~g}\left(\mathrm{~m}^{2}\right)$ & Y1: Paper $55 \mathrm{~g}\left(\mathrm{~m}^{2}\right)$ \\
\hline Y2: Tubete $80 \times 12 \times 15 \mathrm{~cm}(\mathrm{Un})$ & Y2: Tubete $80 \times 12 \times 15 \mathrm{~cm}(\mathrm{Un})$ \\
\hline Y3: Label $(\mathrm{un})$ & Y3: Label $(\mathrm{un})$ \\
\hline Y4: Packing box $\mathrm{n}^{\circ} 4(\mathrm{Un})$ & Y4: Packing box $\mathrm{n}^{\circ} 4(\mathrm{Un})$ \\
\hline Y5: Adhesive tape $48 \mathrm{~mm}(\mathrm{~m})$ & Y5: Adhesive tape $48 \mathrm{~mm}(\mathrm{~m})$ \\
\hline Y6: Box label (Un) & Y6: Box label (Un) \\
\hline
\end{tabular}

The supply chain for the production of the customized two-color POS coil and the one-color POS coil can involve approximately 18 suppliers, as each raw material can have up to three suppliers. The data presented in Tables 2 to 10 and Figures 1 to 7 refer to the production for fiscal year 2012 . 
INDEPENDENT JOURNAL OF MANAGEMENT \& PRODUCTION (IJM\&P)

http://www.ijmp.jor.br

v. 8, n. 5, Special Edition IFLOG 2016

ISSN: 2236-269X

DOI: 10.14807/ijmp.v8i5.617

Table 2 shows the two products analyzed and their composition in terms of the raw materials, the time and cost of production and the sale price.

In Table 2, Y7 production time is expressed in seconds worked to produce a unit, $Y 8$ which is the cost of production of one unit and the sales price $Y 9$ are in Reais.

Table 2: Use of raw material/product, production/product time, cost of production/product and selling price/product 2012

\begin{tabular}{lrrrrrrrrr}
\hline \multicolumn{1}{c}{ Product } & Y1 & Y2 & Y3 & Y4 & Y5 & Y6 & $\begin{array}{r}\text { Time } \\
\text { Y7 }\end{array}$ & $\begin{array}{r}\text { Cost } \\
\text { Y8 }\end{array}$ & $\begin{array}{r}\text { Sale Price } \\
\text { Y9 }\end{array}$ \\
\hline $\begin{array}{l}\text { Customized two-color POS } \\
\text { coil X1 }\end{array}$ & 0,210 & 1 & 1 & 1 & 1 & 1 & 22 & 2,43 & 3,50 \\
\hline $\begin{array}{l}\text { Customized one-color POS } \\
\text { coil X2 }\end{array}$ & 0,190 & 1 & 1 & 1 & 1 & 1 & 19 & 2,15 & 3,15 \\
\hline
\end{tabular}

Table 3 deals with the levels of safety stocks of the two-color custom POS and single-color POS coil products, expressed as percentage values during the 12 months, since the volumes of security stocks may vary, depending on the volume to be produced In the month.

Table 3: Security stock of items to be produced [\%/month] 2012

\begin{tabular}{|l|r|r|r|r|r|r|r|r|r|r|r|r|r|}
\hline & San. & Feb. & March & April & May & June & July & Aug. & Sept. & Oct. & Nov. & Dec. \\
\hline Production Days & 15 & 17 & 21 & 21 & 20 & 20 & 23 & 21 & 21 & 22 & 19 & 12 \\
\hline Resupply Interval & 9 & 14 & 12 & 12 & 15 & 13 & 12 & 12 & 14 & 10 & 10 & 9 \\
\hline ES1 $_{i}$ & 0,0013 & 0,0016 & 0,0018 & 0,0022 & 0,0025 & 0,0018 & 0,0016 & 0,0014 & 0,0016 & 0,0012 & 0,0010 & 0,0008 \\
\hline ES2 $_{i}$ & 0,0014 & 0,0018 & 0,0016 & 0,0018 & 0,0027 & 0,0017 & 0,0018 & 0,0016 & 0,0018 & 0,0013 & 0,0011 & 0,0008 \\
\hline
\end{tabular}

Table 4 shows the proportion of units to be produced per month of each product. Two-color custom POS coil and one color customized POS coil. This ratio may vary depending on the monthly requirement of what should be produced for each model and is based on historical data for the year 2012.

Table 4: Proportion of units to be produced [\%/month] 2012

\begin{tabular}{|l|r|r|r|r|r|r|r|r|r|r|r|r|}
\hline \multicolumn{10}{|c|}{ Proportion of Units to Produce per month } \\
\hline Customized two-color POS coil X1 & 19000 & 28000 & 32000 & 28000 & 30000 & 31000 & 32000 & 35000 & 38000 & 40000 & 40000 & 25000 \\
\hline Customized one-color POS coil X2 & 21000 & 32000 & 29000 & 23000 & 33000 & 29000 & 36000 & 40000 & 42000 & 45000 & 45000 & 27000 \\
\hline
\end{tabular}

Table 5 shows the times available for the production of the products: Twocolor customized POS coil and one color personalized POS coil, during the 12 months of the year, times may be adjusted during the months, and may be increased or decreased, according to need. 
INDEPENDENT JOURNAL OF MANAGEMENT \& PRODUCTION (IJM\&P)

http://www.ijmp.jor.br

v. 8, n. 5, Special Edition IFLOG 2016

ISSN: 2236-269X

DOI: 10.14807/ijmp.v8i5.617

Table 5: Total production time per product [min/month] 2012

\begin{tabular}{|l|r|r|r|r|r|r|r|r|r|r|r|r|}
\hline \multicolumn{10}{|c|}{ Estimated total production time per product per month (minutes) } \\
\hline & Jan. & Feb. & March & April & May & June & July & Aug. & Sept. & Oct. & Nov. & Dec. \\
\hline Customized two-color POS coil X1 & 8708 & 11978 & 14426 & 12481 & 10127 & 13829 & 13804 & 14202 & 14804 & 15529 & 15529 & 11987 \\
\hline Customized one-color POS coil X2 & 8313 & 11822 & 11291 & 8854 & 9621 & 11173 & 13412 & 14018 & 14131 & 15088 & 15088 & 11181 \\
\hline
\end{tabular}

Table 6 shows the quantities to be produced of the two-color custom POS and two-color POS coil products within 12 months, which are calculated by the Excel Solver and the data that were reported in Tables 2, 3 and 4 (Cj), demand (Dj), units to be produced (UPj), and the rate of growth of the supply chain. Cost of annual insurance (hj). Based on this and on Tables 2, 3 and 4, the information regarding the expectation of purchases of raw materials will be generated, already providing for a safety margin in the stock, besides presenting in the objective function the minimization of the costs of production, storage and Acquisition of raw materials, among other factors that can be analyzed.

Table 6: Quantities to be produced [product/month] 2012

\begin{tabular}{|c|c|c|c|c|c|c|c|c|c|c|c|c|c|c|}
\hline Period & Qtd X1 & $\begin{array}{r}\text { Qtd } \\
X 2 \\
\end{array}$ & $c_{j}$ & $D_{j}$ & $C P_{j}$ & $U P_{j}$ & $U c_{j}$ & $U P_{i}$ & $P C_{j}$ & $T C_{i}$ & $A C_{j}$ & $E C_{j}$ & $A D_{j}$ & $E S_{j}$ \\
\hline January & 23750 & 26250 & 0,128300 & 50000 & 87000 & 50000 & 50000 & 50000 & 9975 & 50000 & 50000 & 50000 & 50000 & 0,0014 \\
\hline February & 32667 & 37333 & 0,099200 & 70000 & 87000 & 70000 & 70000 & 70000 & 13953 & 70000 & 70000 & 70000 & 70000 & 0,0017 \\
\hline March & 39344 & 35656 & 0,122500 & 75000 & 87000 & 75000 & 75000 & 75000 & 15037 & 75000 & 75000 & 75000 & 75000 & 0,0017 \\
\hline April & 34039 & 27961 & 0,122500 & 62000 & 87000 & 62000 & 62000 & 62000 & 12461 & 62000 & 62000 & 62000 & 62000 & 0,0021 \\
\hline May & 27619 & 30381 & 0,116700 & 58000 & 87000 & 58000 & 58000 & 58000 & 11572 & 58000 & 58000 & 58000 & 58000 & 0,0026 \\
\hline June & 37717 & 35283 & 0,116700 & 73000 & 87000 & 73000 & 73000 & 73000 & 14624 & 73000 & 73000 & 73000 & 73000 & 0,0018 \\
\hline July & 37647 & 42353 & 0,134700 & 80000 & 87000 & 80000 & 80000 & 80000 & 15953 & 80000 & 80000 & 80000 & 80000 & 0,0017 \\
\hline August & 38733 & 44267 & 0,122500 & 83000 & 87000 & 83000 & 83000 & 83000 & 16545 & 83000 & 83000 & 83000 & 83000 & 0,0015 \\
\hline September & 40375 & 44625 & 0,122500 & 85000 & 87000 & 85000 & 85000 & 85000 & 16958 & 85000 & 85000 & 85000 & 85000 & 0,0017 \\
\hline October & 42353 & 47647 & 0,128300 & 90000 & 95000 & 90000 & 90000 & 90000 & 17947 & 90000 & 90000 & 90000 & 90000 & 0,0012 \\
\hline November & 42353 & 47647 & 0,110800 & 90000 & 95000 & 90000 & 90000 & 90000 & 17947 & 90000 & 90000 & 90000 & 90000 & 0,0011 \\
\hline December & 32692 & 35308 & 0,110500 & 68000 & 87000 & 68000 & 68000 & 68000 & 13574 & 68000 & 68000 & 68000 & 68000 & 0,0008 \\
\hline $\begin{array}{l}\text { Annual } \\
\text { insurance cost } \\
\text { rate } \%\end{array}$ & 0,0155 & 0,0167 & & & & & & & & & & & & \\
\hline $\begin{array}{l}\text { Function } \\
\text { Purpose }\end{array}$ & 201,05 & & & & & & & & & & & & & \\
\hline
\end{tabular}

Table 7 presents the production time data (in minutes) that should be reported by the PCP manager. These data will influence the results of Tables 8, 9 and 10.

Table 7: Total production time estimated by managers per product [min/month] 2012

\begin{tabular}{|l|r|r|r|r|r|r|r|r|r|r|r|r|}
\hline \multicolumn{10}{|c|}{ Estimated total production time per product per month (minutes) } \\
\hline & Jan. & Feb. & March & April & May & June & July & Aug. & Sept. & Oct. & Nov. & Dec. \\
\hline Customized two-color POS coil X1 & 6000 & 12000 & 15000 & 12000 & 11000 & 13500 & 14000 & 14000 & 14900 & 15500 & 15530 & 14000 \\
\hline Customized one-color POS coil X2 & 7000 & 13000 & 11000 & 9000 & 9700 & 11100 & 13400 & 14000 & 14100 & 15100 & 15100 & 14000 \\
\hline
\end{tabular}

Table 8 presents the results regarding the quantity of product that was no longer produced or could be produced, according to the times reported in Table 7 
ISSN: 2236-269X

DOI: 10.14807/ijmp.v8i5.617

and those generated during the execution of the Solver (Table 5).

Table 8: Production losses [product/month] 2012

\begin{tabular}{|c|c|c|c|c|c|c|c|c|c|c|c|c|c|c|c|c|c|c|c|c|c|c|c|c|c|c|}
\hline \multicolumn{27}{|c|}{ Quantities of production losses in units per month } \\
\hline & \multicolumn{2}{|c|}{ Jan. } & \multicolumn{2}{|c|}{ Feb. } & \multicolumn{2}{|c|}{ March } & \multicolumn{2}{|c|}{ April } & \multicolumn{2}{|c|}{ May } & \multicolumn{2}{|c|}{ June } & \multicolumn{2}{|c|}{ July } & \multicolumn{2}{|c|}{ Aug. } & \multicolumn{2}{|c|}{ Sept. } & \multicolumn{2}{|c|}{ Oct. } & \multicolumn{2}{|c|}{ Nov. } & \multicolumn{2}{|c|}{ Dec. } & \multicolumn{2}{|c|}{$G T$} \\
\hline & 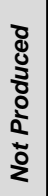 & 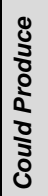 & 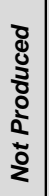 & 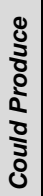 & 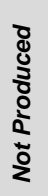 & 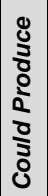 & 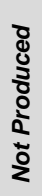 & 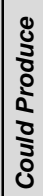 & 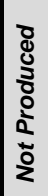 & 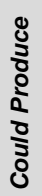 & 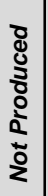 & 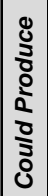 & 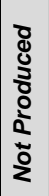 & 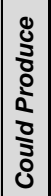 & 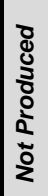 & 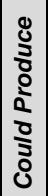 & 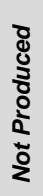 & 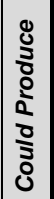 & 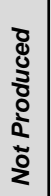 & 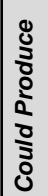 & 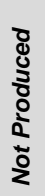 & 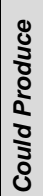 & 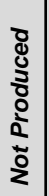 & 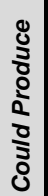 & 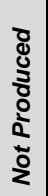 & 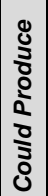 \\
\hline Customized two-color POS coil X1 & $\begin{array}{l}\mathbb{0} \\
\mathbb{N} \\
\sim\end{array}$ & 0 & 0 & 8 & 0 & 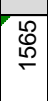 & 퍽 & o & 0 & స్ల & $\begin{array}{l}\infty \\
\infty \\
\infty\end{array}$ & 0 & 0 & 岗 & N & 0 & 0 & $\overrightarrow{0}$ & $\infty$ & 0 & 0 & 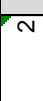 & 0 & $\begin{array}{l}N \\
\infty \\
\infty \\
\infty \\
m\end{array}$ & 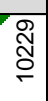 & 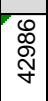 \\
\hline Istomized one-color POS coil X2 & 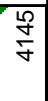 & 0 & 0 & 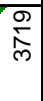 & $\vec{\sigma}$ & 0 & 10 & \& & 0 & 롱 & $\vec{N}$ & 0 & $\hat{m}$ & 0 & 冓 & o & ৪ & 0 & 0 & $\hat{m}$ & 0 & $\hat{m}$ & 0 & ্ֻণ & $\begin{array}{l}0 \\
0 \\
0 \\
n\end{array}$ & $\widehat{\widehat{o}}$ \\
\hline Total & $\begin{array}{l}\overrightarrow{\mathrm{J}} \\
\stackrel{\mathrm{G}}{\mathrm{G}}\end{array}$ & 0 & 0 & 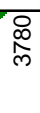 & नु & $\begin{array}{l}\text { 足 } \\
\text { L్య }\end{array}$ & $\underset{\sim}{\mathrm{M}}$ & 8 & 0 & $\widetilde{\widetilde{N}}$ & 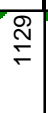 & 0 & $\hat{m}$ & 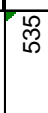 & \& & O & ৪ & $\overrightarrow{\mathrm{d}}$ & $\infty$ & $\hat{m}$ & 0 & m & 0 & $\begin{array}{l}0 \\
0 \\
0 \\
f\end{array}$ & 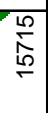 & $\begin{array}{l}m \\
\tilde{O} \\
0 \\
0\end{array}$ \\
\hline
\end{tabular}

Table 9 presents the result regarding possible production losses (in minutes), which refer to what could not be produced or could be produced during the year.

Table 9: Production losses [min/month] 2012

\begin{tabular}{|c|c|c|c|c|c|c|c|c|c|c|c|c|c|c|c|c|c|c|c|c|c|c|c|c|c|c|}
\hline \multicolumn{27}{|c|}{ Production losses in minutes per month } \\
\hline & \multicolumn{2}{|c|}{ Jan. } & \multicolumn{2}{|c|}{ Feb. } & \multicolumn{2}{|c|}{ March } & \multicolumn{2}{|c|}{ April } & \multicolumn{2}{|c|}{ May } & \multicolumn{2}{|c|}{ June } & \multicolumn{2}{|c|}{ July } & \multicolumn{2}{|c|}{ Aug. } & \multicolumn{2}{|c|}{ Sept. } & \multicolumn{2}{|c|}{ Oct. } & \multicolumn{2}{|c|}{ Nov. } & \multicolumn{2}{|c|}{ Dec. } & \multicolumn{2}{|c|}{ GT } \\
\hline & 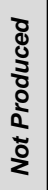 & 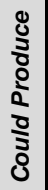 & 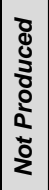 & 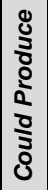 & 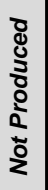 & $\begin{array}{l}8 \\
\vdots \\
0 \\
\vdots \\
0 \\
0 \\
\vdots \\
0\end{array}$ & 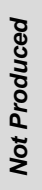 & 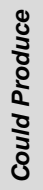 & 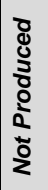 & 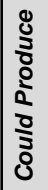 & 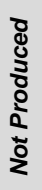 & 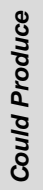 & 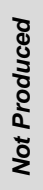 & 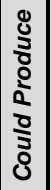 & 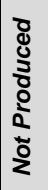 & 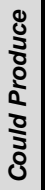 & 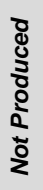 & 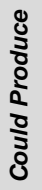 & 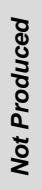 & 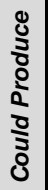 & 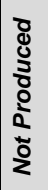 & 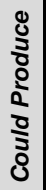 & 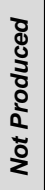 & $\begin{array}{l}8 \\
\vdots \\
0 \\
\vdots \\
0 \\
0 \\
\vdots \\
0 \\
ن\end{array}$ & 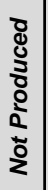 & 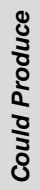 \\
\hline 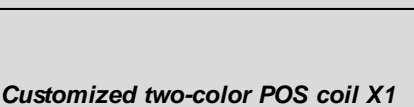 & $\begin{array}{l}\infty \\
\stackrel{\infty}{N} \\
\text { a }\end{array}$ & 0 & 0 & $N$ & 0 & 离 & $\vec{\infty}$ & 0 & 0 & $\underset{\infty}{\infty}$ & న్లి & 0 & 0 & প্] & $\stackrel{\sim}{\sim}$ & 0 & 0 & \% & D & 0 & 0 & 4 & 0 & लm & $\begin{array}{l}\text { 足 } \\
m\end{array}$ & 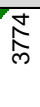 \\
\hline Customized one-color POS coil X2 & $\begin{array}{l}m \\
\vec{g} \\
\rightarrow\end{array}$ & 0 & 0 & $\begin{array}{l}\infty \\
\stackrel{\infty}{7} \\
\exists\end{array}$ & $\vec{N}$ & 0 & 0 & $\underset{\sim}{\stackrel{O}{-}}$ & 0 & R & m & 0 & สิ & 0 & $\underset{\sim}{\infty}$ & 0 & $\vec{m}$ & o & 0 & ㄱ & 0 & 그 & 0 & 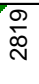 & $\underset{\sim}{\stackrel{N}{\sim}}$ & 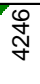 \\
\hline otal & ন্ণ & 0 & 0 & 胥 & $\vec{N}$ & in & $\stackrel{-1}{\sigma}$ & 导 & o & 용 & ণ্ণ & 0 & ㄱ. & Ф & ని & 0 & ले & \& & ని & ก & 0 & & 0 & ্ָ心 & $\begin{array}{l}\infty \\
\infty \\
o ̛ d \\
\vdots \\
0\end{array}$ & ญ్రి \\
\hline
\end{tabular}

Table 10 presents the costs of sales losses and refers to what could not be produced or could be produced during the year. 
INDEPENDENT JOURNAL OF MANAGEMENT \& PRODUCTION (IJM\&P)

http://www.ijmp.jor.br

v. 8, n. 5, Special Edition IFLOG 2016

ISSN: 2236-269X

DOI: 10.14807/ijmp.v8i5.617

Table 10: Cost of sales losses [R \$ / month] 2012

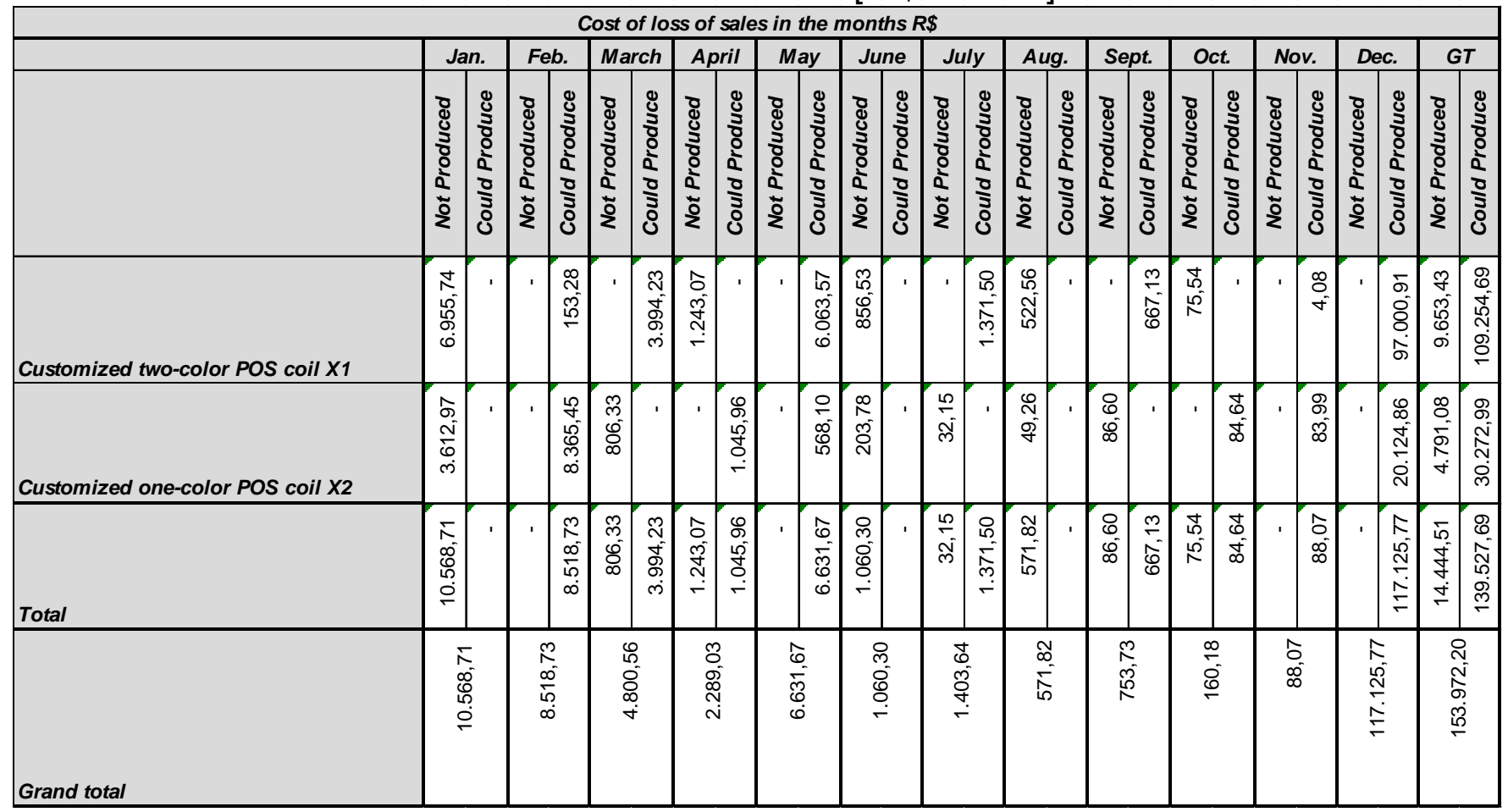

In an attempt to explain the values in Table 2, Figures 1 to 4 were elaborated.

Figure 1 shows the volume to be produced in 2011.

Table 6 presents the monthly demand (DJ) that the company has of the two products, in which it can be observed that it has a significant growth between the months of June and October. Figure 1 shows that the quantities to be produced seek to keep pace with this demand.

\section{Demanda mensal}

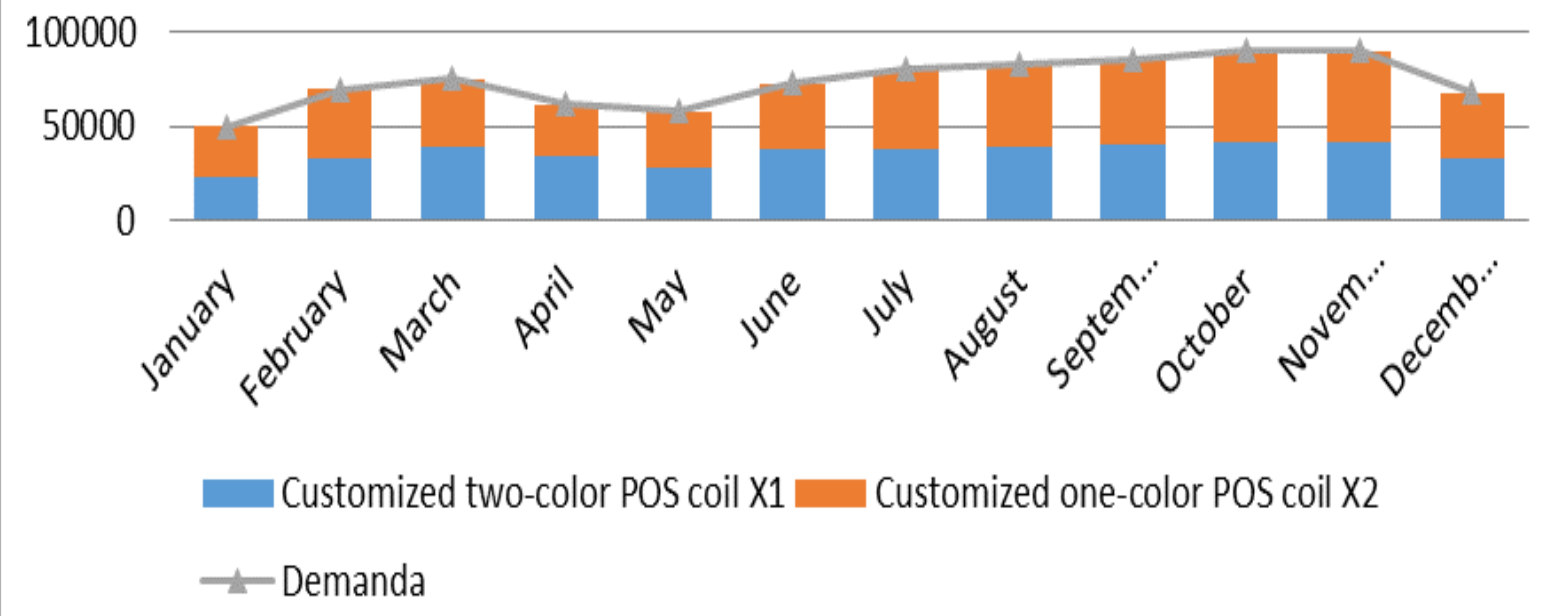

Figure 1: Graphic referring to the volume to be produced 2012 
INDEPENDENT JOURNAL OF MANAGEMENT \& PRODUCTION (IJM\&P)

http://www.ijmp.jor.br

v. 8, n. 5, Special Edition IFLOG 2016

ISSN: 2236-269X

DOI: 10.14807/ijmp.v8i5.617

Figure 2 shows the overall volume of units to be produced during the 12 months of this year 2011 .

\section{Units to be produced}

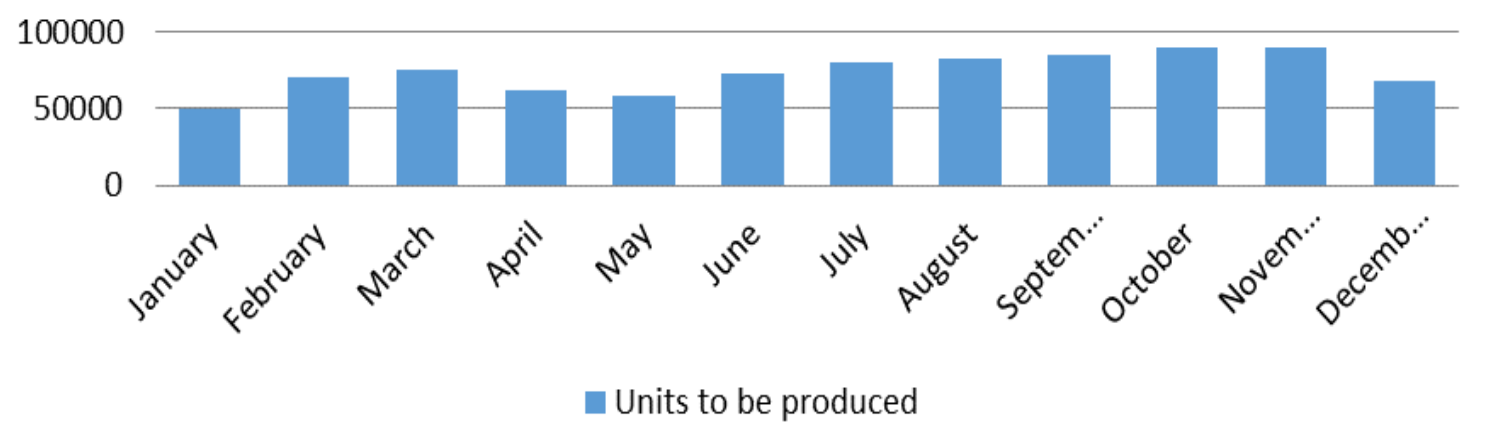

Figure 2: Graph of units to be produced in the 12-month period 2012

Figure 3 shows the evolution of the global security stock in the 12-month period, the percentage values show the period in which it may be smaller or larger, in order to meet emergency requests that may exist.

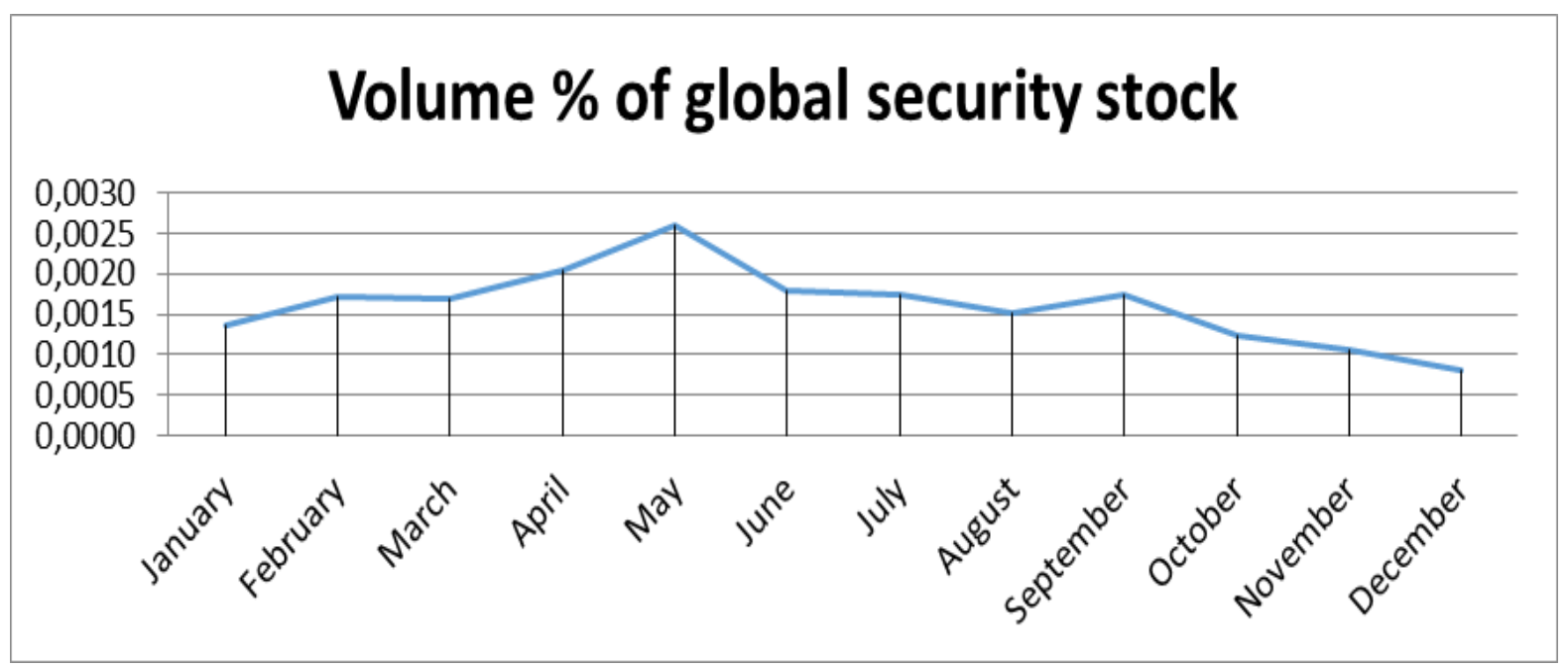

Figure 3: Chart of the volume of security stocks in\% in the period 2012

Figure 4 shows the quantities that were not produced during the year 2011, with the green line referring to the total quantity not produced. 


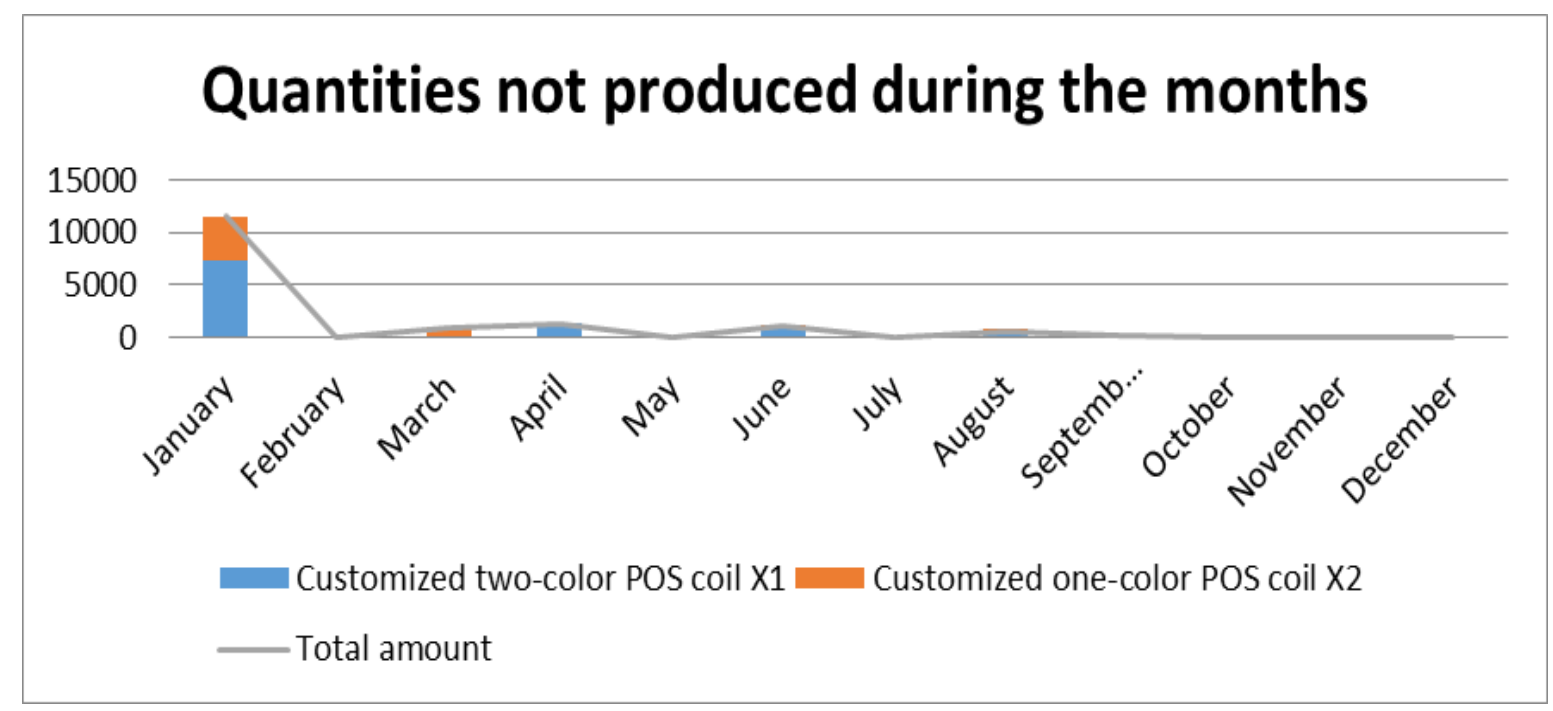

Figure 4: Chart of quantity that was not produced 2012

\subsection{Analysis and validation by the company manager}

The company manager commented that the model was interesting, as it would complement some features that it finds very complex in ERP5 and allows a simple tool to be used and that its employees know, in this case Excel.

\section{Strong points:}

- It allowed the flexibility of decisions on what to produce and the amount of raw material.

$\checkmark$ The model allowed flexibility in decisions about what to produce, the amount of raw material needed and the time of production, since these decisions can be altered and observe the possible consequences. The model also allows a dynamism to be maintained regarding the alteration of the data and consequently to the presented information.

- It allowed the validation of the strategies adopted and the results presented by the ERP5.

$\checkmark$ The results obtained with the model for the year 2012 show that the strategies of purchase of raw material and of production were close to what the company defined. From the graphs presented, it was possible to observe the deviations between the model and the decisions made.

$\checkmark$ With the results presented by the model and ERP5, it was possible to observe how the two software complement each other, when analyzing the strengths and weaknesses of the two applications. 
- It allowed to analyze the demand, productive capacity and seasonality.

$\checkmark$ The results that are based on the demand and the productive capacity of the company were interesting, since it could be observed that the company can study the increase of productivity in certain periods of the year.

$\checkmark$ With the application of the model, it was possible to observe the seasonality that influences the demand and consequently the productivity and thus review the productive strategies, in order to maintain a production that meets the needs not only of the month in question, but also of the next.

- It allowed the application of the model in a considered small company.

$\checkmark$ Because it is a small company and because it does not have so much financial resources, the model has shown to be interesting as support for decision making. And if the model is documented in its routines and the mode of operation can facilitate its application.

$\checkmark$ Based on the model and meetings with the researcher, it was possible to review the way and the variables that made up the cost of production, since the company composed the production cost with the hourly man / machine value, which was then seen as A fixed cost, that is, that regardless of the quantity produced it does not change, starting from this premise the cost of production was revised.

$\checkmark$ The model made it possible to observe more critically the raw materials involved directly in the production of a given product, for example: packaging was considered as a raw material directly involved in the production of the product, which made the cost Of the packaging was part of the cost of production.

\section{Weak point:}

- Lack of costing of raw materials.

The model could make it possible to predict the total costs for the acquisition of raw materials and labor.

Recommendations for improvement: 
- Expansion of results, allowing prediction of inventory levels.

$\checkmark$ The model could be improved with regard to the formulation of the calculation of the safety stock and until it allows the calculation of the minimum stock, informing the maximum time between the request and the arrival of the raw material.

$\checkmark$ A table could also be presented with the result of what should actually be produced, and the quantities of raw material needed for production.

\section{FINAL CONSIDERATIONS}

After the test of the model with the data collected in the company focus of the study, some analyzes were made regarding the consistency of the model and consequent adherence regarding its applicability when defining the productive strategies.

The model allowed to observe about the ways in which some information is obtained and to present the possible deviations that information conflicting or not validated by the management can cause during the execution of the model and the results generated.

The difference between the production times generated by the model and those defined by the manager of company $C$ is relatively low, but one must observe the productive capacity, demand, consumer market of its products and the quantity of products that the company.

The Company's interviewee commented that changes in the definition of production times are being carried out by the company aiming at a production planning that reduces the costs associated with meeting the demand of a particular item, observing the possible seasonality.

The general objective of this work was to "Analyze the influence that a mathematical model focused on the management of raw material stocks in a microenterprise with seasonal demand". It can be affirmed that this objective was successfully achieved, because the mathematical model adhered to the reality of the company's focus of the study.

As can be observed in the previous graphs, this objective was reached, since it presented results that collaborated to minimize the inventory and consequent 
DOI: 10.14807/ijmp.v8i5.617

minimization of storage costs.

\section{REFERENCES}

BAILEY, J. P.; RABINOVICH, E. (2006) The Adoption of Inventory Postponement and Speculation: An Empirical Assessment of Oligopolistic Internet Retailers.

Transportation Research Part E: Logistics and Transportation Review. v. 42, n. 4, p. 258-271.

DARÚ, G. H.; LACERDA, V. C. (2005) Utilização de Programação Dinâmica Multirotulada para Balanceamento do Uso de Ferramenta. In: CONGRESSO NACIONAL DE MATEMATICA APLICADA E COMPUTACIONAL, 28., 2005, São Paulo. Anais... São Paulo: SENAC.

DROHOMERESTKI, E.; CARDOSO, P. A.; COSTA, S. E. G. (2008) Uma análise comparativa entre a estratégia de postergação de tempo e a estratégia de especulação na cadeia de suprimentos: o impacto no estoque. In: ENCONTRO NACIONAL DE ENGENHARIA DE PRODUÇÃO, 28., Rio de Janeiro. Anais... Rio de Janeiro: ABEPRO. 1 CD-ROM

EDALATKHAH, S. T. (2006) Theoretical and experimental investigation of impacto of automatic identification in healthcare \& automotive industries in Iran. Dissertação (Mestrado em Business Administration and Social Sciences). Luleå, Sweden: LTU/TMU.

ENGELSETH, P. (2007) The role of the package as na information resource in the supply chain: a case study of distributing fresh foods to retailers in Norway. Dissertations (Department of Strategy and Logistics), Norwegian: Norwegian School of Management.

FERREIRA, K. A.; BATALHA, M. O. (2007) Condições para aplicação e uso do postponement na indústria de alimentos: o caso da empresa processadora de suco de laranja. In: ENCONTRO NACIONAL DE ENGENHARIA DE PRODUÇÃO, 27., Foz do Iguaçu. Anais... Foz do Iguaçu: ABEPRO. 1 CD-ROM

MCADAM, R.; MCCORMACK, D. (2001) Integrating business processes for global alignment and supply chain management. Business Process Management Journal, v. 7, n. 2, p.113-130.

MENDES, F. D.; LIMA, F. D. M.; FUSCO, J. P. A.; SACOMANO, J. B. (2008) Postergação como estratégia competitiva no segmento jeanswear da manufatura do vestuário de moda - MVM. In: ENCONTRO NACIONAL DE ENGENHARIA DE PRODUÇÃO, 28., Rio de Janeiro. Anais... Rio de Janeiro: ABEPRO. 1 CD-ROM

NG, T. W.; CHUNG, W. (2008) The roles of distributor in the supply chain: push-pull boundary. International Journal of business and management. v. 3, n. 7, p 28-39.

PERAZZA, L., RODRIGUES, P. C. C. (2010) Analysis of performance evaluation model through the balanced scorecard in a footwear industry. Independent Journal of a Management \& Production, v. 1, n. 1, p. 24-36.

DOI: http://dx.doi.org/10.14807/ijmp.v1i1.29

RODRIGUES, P. C. C.; OLIVEIRA, O. J. (2010) Engineering-to-order versus maketo-stock strategy: an analysis at two printing companies. Independent Journal of a Management \& Production, v. 1, n. 1, p. 1-23, http://dx.doi.org/10.14807/ijmp.v1i1.28. 
TAN, K. C. (2002) Supply chain management: practices, concerns, and performance issues, Journal of Supply Chain Management, v. 38, n.1, p.42-53.

VAN HOEK, R. I.; DIERDONCK, R. V. (2000) Postponed manufacturing supplementary to transportation services? Transportation Research Part E: Logistics and Transportation Review, v. 36, n. 3, p. 205-217.

VEROL, M. V. A. (2006) Estratégias logísticas nas empresas de telefonia celular: status e oportunidades na gestão de aparelhos. Dissertação (Mestrado Profissionalizante em Administração). Rio de Janeiro: IBMEC.

WALLIN, C.; RUNGTUSANATHAM, J.; RABINOVICH, E. (2006) What is the "right" inventory management approach for a purchased item?. International Journal of Operations \& Production Management. v. 6, n. 26, p. 50-68.

YANG, B.; BURNS, N. D.; BACKHOUSE, C. J. (2003) The management of uncertainty through postponemen., International Journal of Production Research,v. 42, n. 6, p. 1049-1064.

ZANG, C.; TAN, G. (2010) Classification of Postponement Strategies and Performance Metrics Framework. In: PACIFIC ÁSIA CONFERENCE ON INFORMATION SYSTEMS, 5., 2001. Proceedings Soul, Korea, 20- 22 june, 2001. Disponível em: <http://www.pacis-net.org/file/2001/038.PDF>. Acesso em: mar.

ZINN, W. (1990) O retardamento da montagem final de produtos como estratégia de marketing e distribuição. Revista de Administração de Empresas, v. 4, p. 53-59. 